\title{
GAYA KEPEMIMPINAN DEMOKRATIS GABRIEL ASEM (STUDI KEPEMIMPINAN BUPATI TAMBRAUW PAPUA BARAT)
}

\author{
Karsiman \\ Program Studi Administrasi Negara, FISIP, Universitas Muhammadiyah Sorong
} \begin{abstract}
ABSTRAK
Kepemimpinan adalah sebuah topik yang masih sangat menarik untuk diteliti Kepemimpinan itu esensinya adalah pertanggungjawaban. Jenis penelitian yang dipilih dan dianggap tepat dalam penelitian ini adalah metode deskriptif dengan pendekatan secara kualitatif, pengumpulan data penelitian ini dilakukan dengan berpedoman pada observasi, interview, dan dokumen, yaitu pengumpulan data yang dilakukan melalui bahan-bahan tertulis yang ada hubungannya dengan permasalahan yang diteliti. Dalam penelitian ini pihak yang dijadikan informan adalah Pihak Pemerintah Kabupaten Tambrauw yaitu, Bupati Kabupaten Tambrauw, Wakil Ketua DPRD Kabupaten Tambrauw,Sekda Kabupaten Tambrauw, Pihak dinas pendidikan Kabupaten Tambrauw, Pihak Dinas PU, Pihak BAPPEDA, dan Tokoh Masyarakat Kabupaten Tambrauw. Teknik analisis data yang digunakan dalam penelitian ini teknik analisis taksonomis (taxonomis analysis), yaitu membentuk analisis yang lebih rinci dan mendalam dalam membahas suatu tema atau pokok permasalahan.Berdasarkan hasil penelitian, gaya kepemimpinan bupati Gabriel Asem adalah gaya kepemimpinan demokratis, dengan indikator setiap pengambilan keputusan mengutamakan musyawarah untuk mufakat dan mengutamakan kepentingan rakyat.
\end{abstract}

Kata Kunci: Gaya Kepemimpinan Demokratis, Bupati Tambrauw

PENDAHULUAN

Kepemimpinan secara ilmiah mulai berkembang bersamaan dengan pertumbuhan manajemen ilmiah yang lebih dikenal dengan ilmu tentang memimpin. Hal ini terlihat dari banyaknya literatur yang mengkaji tentang leadership dengan berbagai sudut pandang atau perspektifnya. Leadership tidak hanya dilihat dari bak saja, akan tetapi dapat dilihat dari penyiapan sesuatu secara berencana dan dapat melatih calon-calon pemimpin. Kepemimpinan merupakan proses atau serangkaian kegiatan yang saling berhubungan satu dengan yang lain berisi menggerakkan, membimbing dan mengarahkan serta mengawasi orang lain dalam berbuat sama. Seluruh kegiatan itu dapat disebut sebagai usaha mempengaruhi perasaan, pikiran dan tingkah laku orang lain ke arah pencapaian tujuan.

Kepemimpinan juga bisa diartikan proses interaksi antara pemimpin dengan pegawainya untuk berbuat sesuatu yang sesuai dengan tujuan organisasi. Kepemimpinan pada suatu organisasi sangat ditentukan oleh bagaimana pimpinan mampu menerapkan gaya kepemimpinan yang tepat. Kepemimpinan adalah sebuah topik yang masih sangat menarik untuk diteliti Kepemimpinan itu esensinya adalah pertanggungjawaban. Masalah kepemimpinan masih sangat baik untuk diteliti karena tiada habisnya untuk 
dibahas di sepanjang peradaban umat manusia. Ibaratnya, semakin sulit mencari pemimpin yang baik (good leader). Kesuksesan atau kegagalan suatu organisasi ditentukan oleh banyak hal, yang salah satunya adalah kepemimpinan yang berjalan dalam organisasi tersebut. Seorang pemimpin di hadapkan pada tuntutan pelaksanaan good governance pembangunan yang partisipatif. Demokrasi dijalankan secara konsekuen serta law envorcement. Hal ini hendaknya membawa perubahan mindset pemerintah terutama dalam menjalankan fungsinya sebagai pelayan masyarakat yang menjalankan pemerintahan dan melaksanakan pembangunan.

Kepemimpinan seorang kepala daerah dalam sistem demokrasi dan otonomi daerah merupakan suatu kepemimpinan yang sangat menarik perhatian publik, dimana seorang pejabat publik atau kepala daerah dipilih langsung oleh masyarakat yang akan dipimpinnya, oleh karena itu tentunya tugas dan tanggung jawabnya selalu dalam pengawasan publik. Kepemimpinan Bapak Gabriel Asem sebagai Bupati Tambrauw merupakan contoh kepemimpinan yang menarik untuk dibahas, karena dalam kurun waktu 5 tahun kepemimpinannya, Kabupaten Tambrauw banyak mengalami perkembangan dalam pembangunan dan tata kota serta tata kelola pemerintahan.
Pembangunan daerah di Kabupaten Tambrauw selama lima tahun terakhir banyak mengalami kemajuan, pembangunan tersebut bersifat fisik dan non fisik. Pembangunan daerah di Kabupaten Tambrauw tidak lepas dari sosok pemimpin daerahnya, dimana pemimpin daerah mempunyai peran yang sangat penting dalam kemajuan pembangunan daerahnya. Berdasarkan gambaran singkat tersebut diatas, maka ditulislah sebuah artikel yang berjudul Gaya Kepemimpinan Demokratis Gabriel Assem (Studi Kepemimpinan Bupati Tambrauw Papua Barat).

\section{KAJIAN PUSTAKA}

Memahami kepemimpinan tidak lepas dari perilaku, karakter, gaya memimpin dari individu yang diserahi tugas dan tanggung jawab untuk memimpin. Dari aspek etimologi leadership dapat ditelusuri maknanya dengan mengupas secara harfiah. Pemaknaan secara harfiah lebih cenderung menelusuri asal muasal kata pembentuk konsep tersebut. Kepemimpinan adalah proses mengarahkan dan mempengaruhi aktivitas yang berkaitan dengan pekerjaan dari anggota kelompok.

Mencari sosok pemimpin yang ideal memang bukan pekerjaan yang mudah atau instan, tetapi kita harus bekerja keras untuk selalu melahirkan 
sosok pemimpin yang ideal tersebut. Lebih lanjut secara etimologis istilah kepemimpinan berasal dari kata pemimpin, yang artinya bimbing dan tuntun, dari kata "pimpin" lahirlah kata kerja "memimpin" yang artiya membina atau menuntun, dan kata benda "pemimpin" yaitu orang yang berfungsi memimpin atau membimbing (Kartono, 1998). Kepemimpinan adalah sebuah hubungan yang saling mempengaruhi diantara pemimpin dan pengikut (bawahan) yang mengingkan perubahan nyata yang mencerminkan tujuan bersamanya Rost (Sulistiyani, 2008:13).

Menurut Atmosudirdjo (dalam Purwanto, 1990), Kepemimpinan dapat dirumuskan sebagai suatu kepribadian seseorang yang mendatangkan keinginan pada kelompok orang-orang untuk mencontohnya atau mengikutinya, atau yang memancarkan suatu pengaruh yang tertentu, suatu kekuatan yang sedemikian rupa sehingga membuat sekelompok orang-orang mau melakukan apa yang dikehendakinya. Selanjutnya menurut Haiman (1989) berpendapat bahwa kepemimpinan adalah suatu proses dimana seseorang memimpin, membimbing, direfleksikan dengan jiwa seni. Seni berarti di sini adalah yaitu indah dalam mempengaruhi, indah dalam membimbing, dan indah dalam mengarahkan.
Kepemimpinan adalah faktor yang sangat penting dalam sebuah organisasi. Menurut Kartono dalam Wahyuningsih (2015:2), kepemimpinan adalah masalah relasi dan pengaruh antara pemimpin dan yang dipimpin. Kepemimpinan tersebut muncul dan berkembang sebagai hasil dari interaksi otomatis diantara pemimpin dan individu-individu yang dipimpin (ada relasi interpesonal). Kepemimpinan ini bisa berfungsi atas dasar kekuasaan pemimpin untuk mengajak, mempengaruhi, dan menggerakkan orangorang lain guna melakukan sesuatu, demi pencapaian satu tujuan tertentu. Sedangkan menurut Miftah Thoha dalam Wahyuningsih (2015:2) berpendapat lain kepemimpinan adalah kegiatan untuk mempengaruhi orang lain atau seni untuk mempengaruhi perilaku manusia, baik secara perseorangan atau kelompok.

Dari beberapa definisi di atas, kepemimpinan (leadership) memiliki pengertian sebagai kemampuan yang harus dimiliki seseorang pemimpin (leader) tentang bagaimana menjalankan kepemimpinannya sehingga bawahan dapat bergerak sesuai dengan yang diinginkan dalam mencapai tujuan yang ditetapkan sebelumnya. bergeraknya orang-orang ini harus mengikuti jalur tujuan organisasi yang hendak dicapai dan bukan merupakan hal yang semu dari 
kepemimpinannya itu. Adapun penggerakan dalam pencapaian tujuan adalah legitimasi dari sebuah kekuasaan yang dimiliki oleh pemimpin, karena bukan merupakan simbol atau kedudukan semata.

Menurut Rivai (2008:53) Fungsi artinya jabatan (pekerjaan) yang dilakukan atau kegunaan sesuatu hal atau kerja suatu bagian tubuh. Sedangkan fungsi kepemimpinan berhubungan langsung dengan situasi sosial dalam kehidupan kelompok/organisasi masing-masing, yang mengisyaratkan bahwa setiap pemimpin berada dalam dan bukan diluar situasi itu. Fungsi kepemimpinan merupakan gejala sosial, karena harus mewujudkan dalam interaksi antara individu di dalam situasi sosial suatu kelompok/organisasi. Tugas pokok kepemimpinan yang serupa mengantarkan, mengelompokkan, memberi petunjuk, mendidik, membimbing dan sebagainya yang secara singkat menggerakan enam. Agar para bawahan mengikuti jejak pemimpin mencapai tujuan organisasi, hanya dapat melaksanakan secara baik bila seorang pemimpin menjalankan fungsinya sebagaimana mestinya.

Gaya demoratis, yaitu gaya kepemimpinan yang dikenal pula sebagai partisipatif. Gaya ini berasumsi bahwa para anggota organisasi yang ambil bagian secara pribadi dalam proses pengambilan keputusan akan lebih memungkinkan sebagai suatu akibat mempunyai komitmen yang jauh lebih besar pada sasaran dan tujuan organisasi. Pendekatan tidak berarti para pemimpin tidak membuat keputusan, tetapi justru seharusnya memahami terlebih dahulu apakah yang menjadi 3 sasaran organisasi sehingga mereka dapat mempergunakan pengetahuan para anggotanya, Sudriamunawar dalam Pasolong (2011:47).

Menurut Inu Kencana (2003:27-31) Gaya Demokratis adalah cara dan irama seseorang pemimpin pemerintah dalam menghadapi bawahan dan masyarakatnya dengan memakai metode pembagian tugas dengan bawahan, antar bawahan tugas tersebut dibagi secara adil dan merata. Menurut Sondang P Siagian (2003:27) Tipe yang Demokratis adalah seorang pemimpin yang demokratik dihormati dan disegani dan bukan ditakuti karena perilakunya dalam kehidupan organisasional. Perilakunya mendorong para bawahannya menumbuhkan dan mengembangkan daya inovasi dan kreativitasnya. Dengan sungguh-sungguh ia mendengarkan pendapat, saran dan bahkan kritik orang lain terutama bawahannya. Adpun Bupati adalah kepala untuk daerah kabupaten. Seorang bupati sejajar dengan walikota yakni kepala 
daerah untuk daerah kota . Pada dasarnya, bupati memiliki tugas dan wewenang memimpin penyelenggaraan daerah berdasarkan kebijakan yang ditetapkan bersama DPRD. Bupati dipilih dalam satu paket pasangan dengan wakil bupati melalui Pilkada. Bupati merupakan jabatas politis dan bukan pegawai negeri sipil.

\section{METODE PENELITIAN}

\section{Lokasi dan Rancangan Penelitian}

Penelitian ini dilakukan di Kantor

Bupati Kabupaten Tambrauw. Tipe penelitian ini adalah deskriptif kualitatif, yang berusaha menggambarkan gaya kepememimpinan demokratis bupati Tambrauw.

\section{Informan penelitian}

Dalam penelitian ini pihak yang dijadikan informan adalah Pihak Pemerintah Kabupaten Tambrauw yaitu, Bupati Kabupaten Tambrauw, Wakil Ketua DPRD Kabupaten Tambrauw,Sekda Kabupaten Tambrauw, Pihak dinas pendidikan Kabupaten Tambrauw, Pihak Dinas PU, Pihak BAPPEDA, dan Tokoh Masyarakat Kabupaten Tambrauw.

\section{Metode Pengumpulan Data}

Teknik pengumpulan data dalam penelitian ini adalah dengan wawancara. Dalam penelitian ini, peneliti terjun langsung di Kantor Bupati. Disamping itu peneliti juga melakukan observasi, dalam hal ini peneliti terjun langsung ke lapangan untuk mengadakan observasi mengenai gaya kepemimpinan demokratis bupati Gabriel Asem di Kantor Bupati Daerah Kabupate Selain itu peneliti juga melakukan telaah dokumentasi.

\section{Analisis Data}

Teknik analisis data yang digunakan dalam penelitian ini teknik analisis taksonomis (taxonomis analysis), yaitu membentuk analisis yang lebih rinci dan mendalam dalam membahas suatu tema atau pokok permasalahan. Analisis taksonomi ini digunakan untuk menjabarkan secara rinci kepemimpinan demokrasi dari bapak Gabriel Asem.

\section{HASIL DAN PEMBAHASAN}

Kabupaten Tambrauw merupakan salah satu daerah otonomi di Provinsi Papua Barat yang terbentuk berdasarkan Undang-Undang (UU) Nomor 56 Tahun 2008 tentang Pembentukan Kabupaten Tambrauw di Provinsi Papua Barat, hasil pemekaran dari Kabupaten Sorong. Pembentukan Kabupaten Tambrauw sebagai daerah otonom dimaksudkan untuk memperpendek rentang kendali pemerintahan dalam rangka memberikan pelayanan publik yang lebih baik kepada masyarakat.

\section{A. Mengutamakan \\ Musyawarah}

\section{(keputusan diambil bersama).}




\section{Pemimpin yang efektif}

mempengaruhi pengikutnya dalam berpikir bukan hanya untuk kepentingannya sendiri, melainkan pula untuk kepentingan bersama. Pemimpin adalah katalis yang memiliki tanggung jawab atas segala apapun yang terjadi dalam sebuah organisasi. Kepemimpinan menduduki peran vital dalam organisasi karena seorang pemimpin selain menentukan visi, misi, tujuan dan strategi pencapaian juga bertugas memimpin, mengarahkan, memotivasi anggota kelompok untuk mencapai tujuan. Dalam perbincangan sehari-hari antara konsep kepemimpinan dan manajemen sering di pertukarkan satu sama lain. Secara teknis kegiatan seharihari antara manajer dan pemimpin seolaholah ada kemiripan satu sama lain. sebagai seorang manajer juga melakukan aktivitas kepemimpinan dan sebaliknya sebagai seorang pemimpin juga menjalankan fungsi-fungsi manajemen dilihat dari aspek penekanan adalah efisiensi di dalam menjalanakan fungsi-fungsi manajemen jika menggunakan versi Henry Fayol maka seorang manajer menjalankan fungsifungsi, planning, organizing, staffing,directing,coordinating, reporting, budgeting, sedangkan jika mengikuti terminology George R. Terry maka manajer menjalankan fungsi planning, organizing, actuating, dan controlling.
Kepemimpinan adalah suatu usaha menggunakan suatu gaya mempengaruhi dan tidak memaksa untuk memotivasi individu dalam mencapai tujuan. Kepemimpinan juga melibatkan penggunaan pengaruh dan semua hubungan dapat melibatkan kepemimpinan. Kepemimpinan yang efektif adalah merupakan hasil dan kombinasi yang tepat antara situasi yang menyenangkan dan gaya kepemimpinan. Bupati Gabriel Asem dalam memimpin Kabupaten Tambrauw telah menunjukkan hasil yang kongkrit terutama di bidang pembangunan infrastruktur. Dalam proses pengambilan keputusan Bapak Bupati Tambrauw selalu mengutamakan musyawarah untuk mencapai kata sepakat.

Hasil wawancara peneliti dengan Kepala Bidang Pendidikan Dasar Dinas Pendidikan Kabupaten Tambrauw AL, mengemukakan bahwa:

",......Pak Bupati bagus dalam kepemimpinan selalu memperhatikan peningkatan mutu pendidikan di Kabupaten Tambrauw, beliau senantiasa memanggil kami rapat untuk membicarakan bagaimana peningkatan mutu pendidikan di Kabupaten Tambrauw. dari tahun 2010 berjalan pembangunan sampai sekarang, dalam bidang pendidikan itu Guru-guru disekolahkan, bahkan olimpiade nasional sains kita telah sampai di Palembang. Memang untuk pendidikan secara fisik Gedunggedung sekolah sudah dibangun 
cuma kendalanya kami adalah kekurangan guru tapi kami telah kerjasama dengan UNG untuk menjawab kekurangan guru". (Hasil wawancara, 6 Desember 2017).

Hasil wawancara peneliti dengan pihak PU yang diwakili oleh Kepala Sub Bagian Umum yang berisial GA, mengemukakan bahwa:

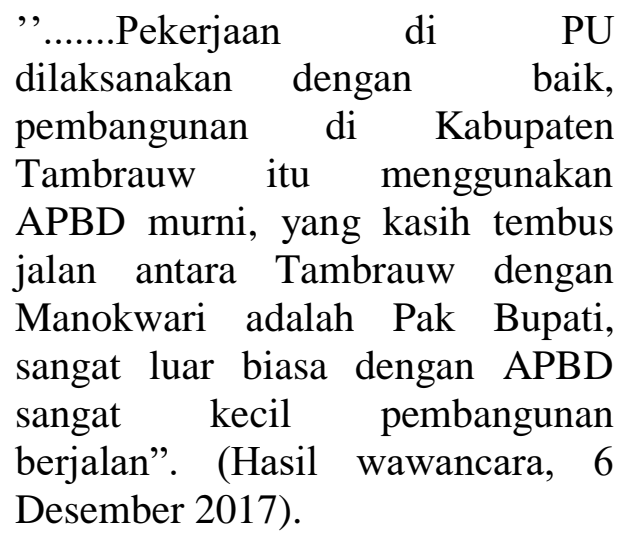

Merupakan salah satu tantangan terbesar dalam pembangunan di Kabupaten Tambrauw adalah keterbatasan biofisik kawasan. Kawasan pesisir dan laut, hutan dataran rendah, hingga pegunungan tinggi. Tofografi Tambrauw hampir $40 \%$ kemiringan lahan. Hampir 80\% merupakan kawasan hutan lindung, hutan konservasi, bahkan di beberapa hulu sungai, terdapat deposit tambang yang cukup tinggi . Dari aspek budaya dan adat istiadat, sebagian besar wilayah Tambrauw merupakan daerah wilayah keramat pendidikan adat inisiasi wuon woffl. Hampir semua kampung dan distrik berada dalam kawasan cagar alam, namun tantangan tersebut dijawab Bapak Gabriel Asem untuk melakukan pembangunan di Kabupaten Tambrauw dengan memastikan bahwa hak-hak masyarakat adat serta keberlanjutan ekosistem hutan, flora, fauna, dan potensi budaya tetap ada.

\section{B. Mengutamakan}

kesejahteraan

\section{Masyarakat}

Dalam kegiatan pelaksanaan pembangunan infrastruktur yang dilakukan menunjukkan bahwa bapak bupati selalu berupaya memberikan jaminan atas pembangunan infrastruktur yang benarbenar mampu meningkatkan pembangunan demi kesejahteraan masyarakat Kabupaten Tambrauw. Hal tersebut berdasarkan hasil wawancara peneliti dengan informan yang merupakan Sekretaris BAPPEDA inisial YA, mengemukakan bahwa:

",.......Pada periode 1 masa kepemimpinan Pak Bupati Gabriel Asem, prioritas yang dilakukan adalah pembangunan infrastruktur dasar karena itu yang sangat dibutuhkan masyarakat dan memang juga merupakan prioritas kerja dari Bupati. Kami telah membangun 9 jembatan dengan APBD. Cuma kesulitan kami adalah SDM di Kabupaten Tambrauw masih kurang". (Hasil wawancara, 6 Desember 2017).

Hasil wawancara dengan wakil ketua DPRD Kabupaten Tambrauw inisial FB mengemukakan bahwa:
',.......Beliau
membangun demi kepentingan masyarakat bukan kepentingan pribadi, sekarang 
masyarakat sudah menikmati, kalau dulu perjalanan ke Sorong 1 minggu sekarang tinggal 1 hari, kami di DPRD juga selalu mendukung apa yang dilakukan oleh Pak Bupati demi kesejahteraan masyarakat Tambrauw". (Hasil wawancara, 7 Desember 2017).

Pemimpin yang berhasil adalah pemimpin yang senantiasa mengutamakan kepentingan rakyatnya bukan kepentingan pribadi maupun kelompoknya. Bapak Bupati Gabriel senantiasa mengutamakan kesejahtera masyarakat Tambrauw maka pantas Bapak Gabriel Asem dijuluki Bapak pembangunan Tambrauw. Berdasarkan hasil wawancara dengan SEKDA Kabupaten Tambrauw inisial EK, mengemukakan bahwa:

',........Keberhasilan Bapak Bupati jelas, membangun Tambrauw meski dengan keterbatasan anggaran, kita bangun 9 jembatan pakai APBD sendiri, mendapatkan penghargaan satya lencana dari presiden adalah bukti keberhasilan Bapak Bupati”. (Hasil wawancara, 6 Desember 2017).

Hasil wawancara dengan tokoh masyarakat Tambrauw inisial YY, mengemukakan bahwa:

',........Dulu perjalanan ke Tambrauw butuh waktu yang berhari-hari, sekarang masyarakat sudah menikmati pembangunan oleh Bapak Gabriel Asem. Pembangunan jalan, jembatan memudahkan perjalanan dari Sorong ke Tambrauw'. (Hasil wawancara, 6 Desember 2017).
Berdasarkan hasil wawancara diketahui bahwa Bapak Gabriel Asem senantiasa mengutamakan pembangunan infrastruktur dasar demi kesejahteraan masyarakat Tambrauw, seperti pembangunan Jembatan yang hanya menggunakan APBD Kabupaten Tambrauw. Pembangunan jalan dan jembatan yang telah dilakukan merupakan program prioritas dalam membuka isolasi daerah Tambrauw, pembangunan jalan dimaksudkan untuk menghubungkan pusat-pusat pemukiman kampung, distrik, dan ibukota Kabupaten Tambrauw. Karena dengan itu semua, masyarakat akan mendapatkan pembangunan yang maksimal, tetapi juga mereka juga akan memiliki akses untuk bersentuhan langsung dengan pasar di Kota atau mereka bisa berbisnis skala kecil tanpa melalui retailer yang selama ini mempermainkan harga-harga barang kebutuhan sehari-hari.

\section{KESIMPULAN}

Berdasarkan hasil penelitian maka dapat ditarik kesimpulan sebagai berikut :

a. Kepemimpinan Bupati Gabriel Asem adalah kepemimpinan demokratis, hal tersebut sesuai dengan indikator, yaitu:

1. Mengutamakan musyawarah: Bapak Gabriel Asem selalu menjaga komunikasi yang baik antara bawahannya atau jajarannya dengan 
mengadakan musyawarah terlebih dahulu sebelum memutuskan atau mengambil sebuah keputusan.

2. Mengutamakan kesejahteraan masyarakat: Bapak Gabriel Asem senantiasa mengutamakan pembangunan infrastruktur dasar demi kesejahteraan masyarakat Tambrauw, seperti pembangunan Jembatan yang hanya menggunakan APBD Kabupaten Tambrauw. Pembangunan jalan dan jembatan yang telah dilakukan merupakan program prioritas dalam membuka isolasi daerah Tambrauw.

\section{SARAN}

Setiap kepala daerah memiliki ciri khas tersendiri dalam memimpin daerahnya. Bapak Gabriel Asem adalah pemimpin yang peduli dengan rakyat, yang telah membangun Kabupaten Tambrauw dari ketertinggalan dan mensejajarkan dengan daerah lain yang ada di Papua. Untuk itu hendaknya kepemimpinan Bapak Gabriel Asem di Kabupaten Tambrauw ditiru oleh kepala daerah lain di Papua yang masih tertinggal daerahnya.

\section{DAFTAR PUSTAKA}

Kartono, Kartini, (2014 ) Pemimpin dan Kepemimpinan” Jakarta, Rajawali Press.
Pasolong, Harbani, (2008) Teori Administrasi Publik, Bandung, Alfabeta.

Pasolong, Harbani, (2010) Kepemimpinan Birokrasi, Bandung, Alfabeta.

Siagian, Sondang P.(1999) Manajemen Sumber Daya Manusia. Jakarta : Bumi Aksara.

Titit, Gabriel dkk, (2017) Gabriel Asem Peletak Dasar Pembangunan Tambrauw- Papua Barat ( Pemimpin Visioner, Tegas, Cerdas, Rendah Hati, dan Penggerak Lingkungan) , Yogyakarta, Deepublish.

Thoha, Miftah, (2012 ) Perilaku organisasi, dimensi-dimensi prima ilmu administrasi negara" Jakarta, PT Rajawali.

\section{PROFIL SINGKAT}

Penulis bernama Dr. H. Karsiman, M.Si. Penulis merupakan Dosen FISIP Universitas Muhammadiyah Sorong dan merupakan Alumni Program Doktor Ilmu Sosial Universitas Merdeka Malang. Fokus kajian penelitian penulis yakni kepemimpinan dan kebijakan publik. 